\title{
Significance of petroleum seepages in hydrocarbon exploration-case study of Khourian Desert, Central Iran
}

\author{
Azadeh Hosseini $^{1} \cdot$ Mohammad Hossein Saberi $^{1}$ [D $\cdot$ Bahman ZareNezhad $^{2}$
}

Received: 9 November 2021 / Accepted: 21 December 2021 / Published online: 29 December 2021

(c) The Author(s) 2021

\begin{abstract}
Hydrocarbon exploration has long been based on such costly and time-intensive methods as geophysical surveys, geological studies, and drilling. In recent years, however, researchers have started to consider such inexpensive alternatives as surface geochemistry for hydrocarbon exploration. Some 100 years ago, the leakage of hydrocarbons onto the surface in the form of micro- and macro-seepages motivated researchers toward drilling a well in the Khourian Desert in the south of Semnan Province, Iran. Upon drilling the well, researchers found evidences of non-released (free) hydrocarbons. These findings drove further study of the area using surface geochemistry while considering the nearby hydrocarbon accumulation in Qom Formation. Conventional and indirect surface geochemical methods provide an insight into the relationship between surface and subsurface hydrocarbons. In the present work, the results of the Rock-Eval pyrolysis showed total organic carbon (TOC) values in the range of $0.31-4.13 \mathrm{wt}$. $\%$ and $\mathrm{S}_{1}$ peaks between 0.07 and 27.35. Sulfur isotope analysis showed a sulfur isotopic value of -0.4 . The study of hydrocarbon-oxidizing bacteria showed the presence of bacterial colonies in MSM at $1.22 \times 10^{6} \mathrm{cfu} / \mathrm{g}$ of soil sample. We further investigated surface changes due to the presence of free hydrocarbons and $\mathrm{pH}$ variations (4.9-8) resulted from the changes in the concentrations of calcium carbonate and iron. According to the results and given the presence of organic sulfur in the samples, the occurrence of Gach-i-turush and alike phenomena was proposed in this area. The results of geo-microbial prospecting method, surface secondary changes, and sulfur isotope studies were well in agreement with the characteristics of the existing hydrocarbon reserves in this area. Surface geochemical surveys can precede other geochemical and geophysical surveys to identify surface anomalies and hence focus on more probable locales of hydrocarbon accumulation in the Khourian Desert, central Iran.
\end{abstract}

Keywords Surface geochemistry $\cdot$ Rock-Eval pyrolysis $\cdot$ Sulfur isotope $\cdot$ Geo-microbial prospecting $\cdot$ Calcium carbonate contents · Central Iran Basin

\section{Introduction}

Oil and gas exploration across Central Iran Basin (CIB) can be traced back to 1934 when the earliest oil seepage was observed in Haft Mil Mountains in the south of Qom. Later

Mohammad Hossein Saberi

mh.saberi@semnan.ac.ir

Azadeh Hosseini

azade_hosseini@semnan.ac.ir

Bahman ZareNezhad

bzarenezhad@semnan.ac.ir

1 Faculty of New Science and Technology, Department of Petroleum Engineering, Semnan University, Semnan, Iran

2 Faculty of Chemical, Petroleum and Gas Engineering, Semnan University, Semnan, Iran on, the Alborz Oilfield was discovered in the 1950s after drilling on top of the Alborz Anticline $10 \mathrm{~km}$ to the north of Qom city. Then, Sarajeh condensate gas reservoir was discovered in an area between Qom and Kashan in the 1960s, with the discovery being a result of surface structure studies and a seismic survey (Bin and Meiyin 2010).

These facts, however, did not conceal the obvious evidence that the hydrocarbon has actually been formed in the Oligo-Miocene deposits within the CIB, as substantiated by the following oil shows:

(1) Leakage of light oil from Upper Oligocene limestones into an aqueduct (a series of wells interconnected by an underground water channel) in the south of Qom, 
(2) A large seep of relatively heavy oil leaking through the gypsiferous marly horizons in the Mil Area, $25 \mathrm{~km}$ to the west of Qom,

(3) Bituminous shales in the evaporites exposed in the Qom and Semnan regions,

(4) A light oil seep from the marly Lower Miocene limestone in the core of the Kuh Gugird structure $80 \mathrm{~km}$. southwest of Semnan.

(5) The oil in salt mines developed in diapiric salt masses $80 \mathrm{~km}$ to the east and southeast of Tehran,

(6) Bitumen in sulfur mines explored along the fault line in the Upper Red Formation within $30 \mathrm{~km}$ of a Semnan. The association is comparable to the "Gach-i-turush" (an originally Persian phrase meaning "sour gypsum", a result of reaction between gypsum and acid) of the southern oilfield belt, where hydrocarbon gases have reacted with gypsiferous formations (Gansser 1955).

The present study reports an attempt for discovering crude oil and natural gas deposits in the south of Semnan. Generally known as the Dash-i-Kavir-i-Khourian (Khourian Desert), the study area lies immediately to the south of the town of Semnan in the northern CIB. It is further bordered by the Semnan Salt Kavir in the east and the Ginab River and the Delazian Kavir in the west (Fig. 1) (Abdullahzadeh 1995).

We know that some hydrocarbon discoveries have been done in this area in the past although an official report on such discoveries is yet to be released. Widely known as conventional hydrocarbon exploration methods, geological and geophysical surveys and drilling are very costly and timeconsuming (Japperi et al. 2019). Geochemical exploration methods, on the other hand, are relatively inexpensive and fast methods that have been used to somewhat complete the geophysical methods. The basic assumption considered in any surface geochemical exploration survey is that the hydrocarbons that are originally produced or trapped in depth are found in different forms that can eventually leak to the surface (Rabbani 2017). Integration of the findings of geochemical studies with those of geological and seismic methods lowers the risk of going for eventually dry exploratory wells (Schumacher 2017; Sechman et al. 2020).

The first attempts for implementing geochemical methods for oil and gas prospecting were done in the 1930s and early 1940s. These included the works by Sokolov (1933) in Russia, Laubmeyer (1933) in Germany, and Horvitz (1939) and Rosaire (1940) in the USA (Sokolov 1933; Laubmeyer 1933; Horvitz 1939; Rosaire 1940). These preliminary studies were, however, limited to the analysis of methane and total non-methane hydrocarbons in the soil gases (Philp and Crisp 1982). Surface geochemical surveying refers to a wide variety of direct and indirect methods. In this respect, a direct method is one that measures actual hydrocarbon

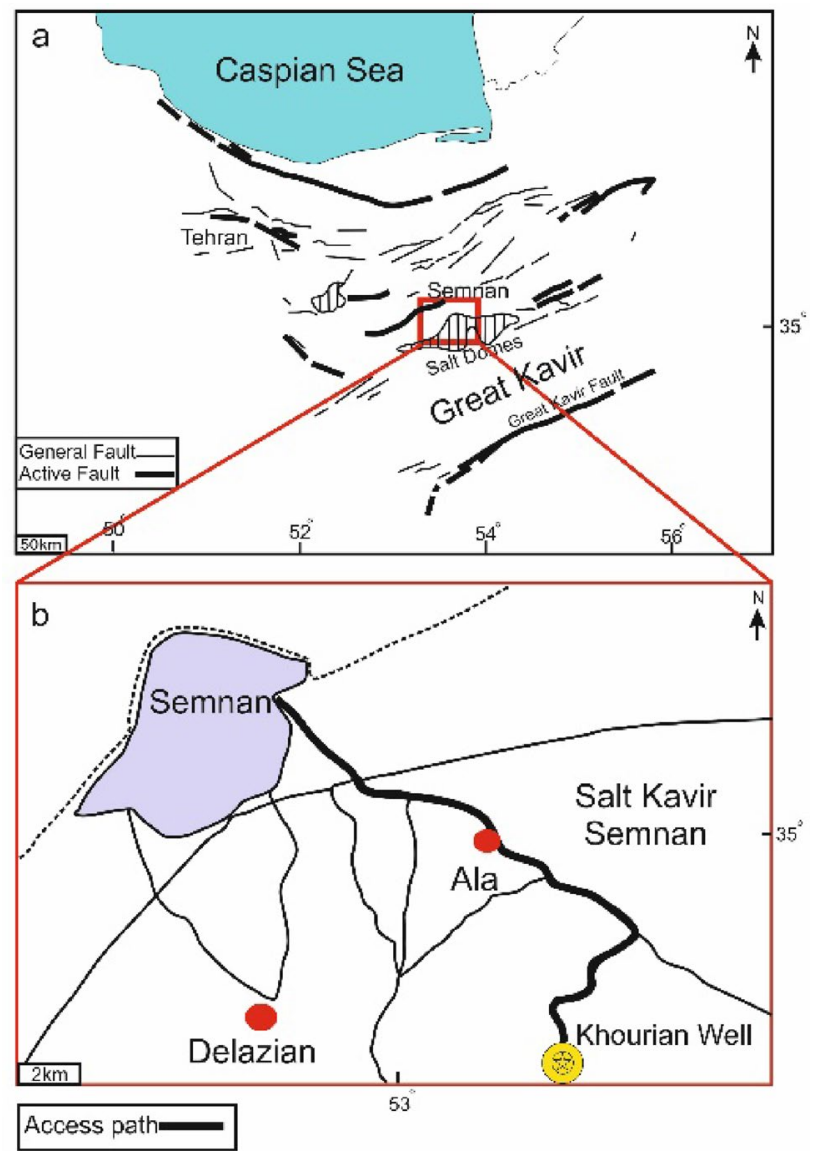

Fig. 1 Location maps of a Semnan Province in the CIB and b Khourian Desert (modified after (Rahimpour-Bonab et al. 2007))

concentration in the sample (usually in the form of vapor in the soil, water, atmosphere, or sediment) (Sokolov 1933; Sechman and Dzieniewicz 2011; Tedesco 2012; Sechman et al. 2015, 2020).

Many researchers have developed indirect surface geochemical methodologies to record particular physical and/ or chemical changes that occur to a rock formation as the hydrocarbon migrates to the surface (Sechman et al. 2020). As an indirect geochemical method, hydrocarbon-oxidizing bacteria have been regarded as they are usually abundant in the shallow soils/sediments located above the hydrocarbonbearing strata. The basis for microbial detection of petroleum lies in the bacteria's ability to metabolically oxidize some portion of the hydrocarbons as they migrate through and out of the soil substrate (Philp and Crisp 1982; Yuan et al. 2009; Tedesco 2012; Rasheed et al. 2015; Varjani 2017).

Light hydrocarbons are known to be consumed by phylogenetically diverse groups of bacteria belonging to the Brevibacterium, Corynebacterium, Flavobacterium, Mycobacterium, Nocardia, Pseudomonas, and Rhodococcus genera. Microbial anomalies have been proven to be reliable 
indicators of oil and gas in the subsurface (Rasheed et al. 2012a). Application of hydrocarbon-oxidizing bacteria in petroleum exploration has been considered as an effective tool (Wagner et al. 2002; Miqueletto et al. 2011; Rasheed et al. 2015, 2017; Zhou et al. 2020). The success of microbial prospection for oil and gas has been reported to be around 90\% (Wagner et al. 2002; Rasheed et al. 2011).

In principle, specific microbes may synchronously respond to the dynamic variations of the reservoir pressure and fluid distribution in subsurface soils/sediments above a hydrocarbon reservoir. Thus, microbial indicators can also be employed to characterize the distribution of remained oil/ gas within mature production fields for delineating the field and contributing to the field development and management in during the field production life. Some successful cases of microbial reservoir characterization have already been reported. Examples include Sacramento Basin in California, Kingfisher County in Oklahoma, and another work in Germany (Wagner et al. 2002; Rasheed et al. 2011; Zhou et al. 2020).

Rasheed et al. (2008, 2012a, b, c, 2017) collected soil samples from India and determined their hydrocarbon contents by examining the hydrocarbon-oxidizing bacteria (Baum et al. 2008; Rasheed et al. 2012a, 2012b, 2017). The possibility of hydrocarbon exploration using microbiological method is emphasized by the fact that the hydrocarbonoxidizing bacteria exhibit some $10^{3}-10^{6}$ colony forming units per gram (cfu/g) of hydrocarbon-bearing soil/sediment depending on ecological conditions (Rasheed et al. 2017).

Other indirect geochemical method include magnetic susceptibility measurement and calcium carbonate content analysis on the soil. Many publications have demonstrated the relationships between hydrocarbon migration from deep accumulations and the formation of magnetic minerals (Sechman et al. 2020). Diagenetic carbonates and carbonate cements are among the most common hydrocarbon-induced alterations associated with petroleum seepages. Pore-filling calcite and replacement calcite are also common (Yang et al. 2000). Many of surface geochemical techniques are affected by $\mathrm{pH}$ conditions of the sampled soil and rock strata in one way or another. Only recently the researchers of soil science have concentrated on the $\mathrm{pH}$ and its effect on chemical and biological processes in the soil substrate. Leakage of petroleum into the second layer of the soil (usually containing hydrocarbon, minerals, and bacteria) causes several chemical reactions including the microbial oxidation of hydrocarbons, further decreasing the $\mathrm{pH}$ (Tedesco 2012). Sechman et al. (2020) carried out a surface geochemical survey in Poland. The results showed significant relationships among calcium carbonate content, magnetic susceptibility, and $\mathrm{pH}$ values of the soil samples and hydrocarbon sources in the region (Sechman et al. 2020). Migration and leakage of hydrocarbon into the surface tends to reduce the
$\mathrm{pH}$ of the surrounding medium, causing the deposition of particular metals along with hydrocarbons. These metals include iron oxides and iron sulfides and their precipitation induce some changes to the soil. Measuring these changes help identify the corresponding hydrocarbon reserves (Philp and Crisp 1982; Tedesco 2012; Sechman et al. 2020). In his report on the Persian Gulf-Iraq petroleum belt, Thompson noted that the pyrite and sulfur are commonly found in hydrocarbon-containing regions (Thompson et al. 1994). He further figured out that the carbonate was replaced by gypsum and anhydrite minerals in the sealing rocks of the salt dome in the region. Another product of alteration in the petroleum-bearing areas is a result of the reaction between hydrocarbons and evaporative minerals: Gach-i-turush (Rabbani 2017).

The present paper reports an attempt to investigate the presence/absence of hydrocarbons in Khourian Desert by using surface geochemical methods, namely microbial assessments and study of mineralogical changes, magnetic susceptibility and calcium carbonate content. Other geochemical methods performed in this paper include Rock-Eval pyrolysis and sulfur isotope analysis, which were done to evaluate the changes in the subsurface and characterize the $\mathrm{OM}$

\section{Geological setting}

The study area is situated in the central Iran tectonic zone, north of the Great Kavir Basin (Fig. 1). The Cenozoic sediments of the CIB and its eastern sector, the Great Kavir Basin, exhibit only subtle variations across the area, although some regional differences are evident. The Cenozoic deposits of the Great Kavir Basin form an intra-continental rift basin filled with several kilometers of Eocene to recent marine and continental sediments (mainly evaporites, carbonates, and red beds). To the south of the city of Semnan, these sediments occur as about 50 very large salt diapirs hosting Eocene to Miocene evaporites, limestone strata, and continental red beds (Rahimpour-Bonab et al. 2007).

The CIB is one of the most important sedimentary basins in Iran. With its triangular geometry, the CIB is adjacent to the Lut Block in the east, the Alborz Mountain in the north, and the Sanandaj-Sirjan Zone in the south (Ghorbani 2013). The CIB is developed between the geologically better-known regions of Zagros and Alborz Mountain. Seeking for hydrocarbon exploration, researchers have studied the Late Eocene-Holocene evolution of the CIB based on seismic surveys, geological field works, basin modeling efforts, and remote sensing studies. According to the results of such studies, the basin history has commenced with a broad sagtype subsidence and isolated normal faults developed during the Oligocene-Early Miocene time (Morley et al. 2009). 
Three main stratigraphic units have been identified in the CIB: (1) Lower Red Formation (Oligocene), (2) Qom Formation (Late Oligocene-Early Miocene), and (3) Upper Red Formation (Early Miocene-early Pliocene) (Fig. 2).

During Eocene, the CIB has been generally experiencing a rifting stage with very strong volcanic activities. Composed mainly of volcanic rocks, the Lower Red Formation (LRF) has been deposited in an arid to shallow-water environment (Bin and Meiyin 2010).

Deposition of the Qom Formation has been coeval with the onset of the continental collision between the Iranian Plate and the Zagros Platform (Mohammadi 2020). The formation of the Oligo-Miocene Qom Back-Arc Basin has been a result of the subduction of the Neotethys oceanic crust beneath the CIB, resulting in the formation of a backarc opening, deposition of the Qom Formation, and alkaline volcanic processes (Berberian 1983). The marine constituents of the Qom Formation began to deposit in such a back-arc basin characterized by arid climate, relatively stable

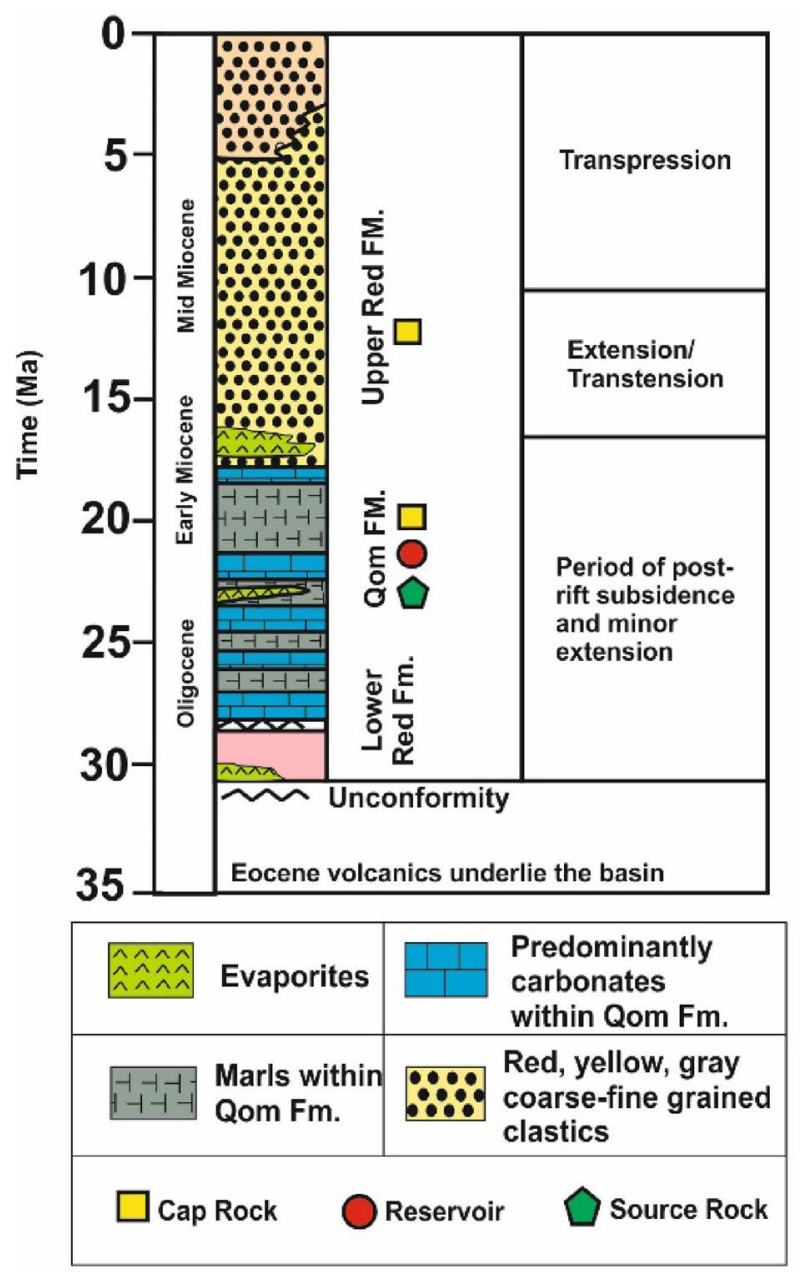

Fig. 2 Stratigraphic column of the study area (modified after (Morley et al. 2009)) basement, soft volcanic eruptions, alternative closing and opening of seawater passage by the gate of southern island arc due to the periodic eustatic sea level changes, and subtectonic depositional setting of the basin, slope, shelf, and island arc (Bin and Meiyin 2010). The limestones of Qom Formation are followed by thick continental red beds of the Upper Red Formation (URF) (Mohammadi 2020). The CIB was connected to the open sea (Persian Sea) via some channel until the Middle Miocene, after when the connection was almost closed by the uplifting Zagros Mountains, bringing the deposition of Qom Formation to stop while contributing to the terraneous sedimentation of Upper Red Formation (URF). Later on, major uplifts occurred to the Alborz (in the north) and Zagros Mountains (in the south) during Pliocene to Quaternary, giving rise to foreland basins in front of the two fold-thrust belts (Bin and Meiyin 2010).

The Lower Red Formation is typically $300-1000 \mathrm{~m}$ thick and varies in lithology both laterally and vertically. It is composed, mainly, of shale, siltstone, gypsiferous marl, sandstone, conglomerate, and evaporites (Gansser 1955). The coarse-grained clastic sediments show large amounts of Eocene volcanic-derived clasts. Basaltic-andesitic lava flows and pyroclastic deposits also occur in some places. The occasional presence of marine fossils indicates episodic marine incursions into the basin. A halite-dominated evaporite sequence a thickness of several hundreds of meters exists in the base of the LRF (Morley et al. 2009).

The Qom Formation is a Late Oligocene-Early Miocene shelfal-upper slope marine carbonate-dominated unit (Morley et al. 2009). Reuter et al. (2009) dated the Qom Formation back to Late Rupelian to Middle Burdigalian, making it a time-equivalent to the Limestones of Asmari Formation of the Zagros Mountain, with both of the formations recording the Terminal Tethyan Event (the closing of the Tethyan Seaway due to the uplift associated with the collision of the Arabian and Eurasian plates) (Reuter et al. 2009). The Qom Formation marks an isolated branch of the Tethyan Seaway in the north of the main ocean (Morley et al. 2009). With an overall thickness of $1200 \mathrm{~m}$, it is composed of nine lithologically identifiable members, which are designated as Members a, b, c1, c2, c3, $\mathrm{c} 4, \mathrm{~d}, \mathrm{e}$, and $\mathrm{f}$ (Member $\mathrm{a}=$ basal limestone, Member $\mathrm{b}=$ sandy marls, Members c1, c2, c3, and c4=alternating marls and limestones, Member $\mathrm{d}=$ evaporites, Member $\mathrm{e}=$ green marls, and Member $\mathrm{f}=$ top limestone) (Aghanabati 2004; Reuter et al. 2009; Bin and Meiyin 2010). Due to its various facies content, the Qom Formation has served as source rock, reservoir rock and cap rock in different areas (Gansser 1955; Jaafari 1963; Morley et al. 2009; Rezaei and Honarmand 2002; Kongwung et al. 2009; Morley et al. 2013; Mohammadi et al. 2019; Mohammadi 2020). The carbonates of the Qom Formation are most commonly representative of outer shelf-upper slope deposition on a ramp-type setting, with bryozoan assemblages dominating over corals (Morley et al. 2009). The formation is 
mainly sealed by Lower Miocene evaporites, predominantly halite, which form the basal part of the LRF in the vicinity of the Alborz and Sarajeh anticlines. The evaporites are typically about 400-m thick (Morley et al. 2013).

The Upper Red Formation is a clastic-dominated unit with a thickness varying from 300 to $1000 \mathrm{~m}$. It is composed of shale, marl, siltstone, sandstone, and conglomerate. At the base of the formation, there is an evaporite unit with a thickness of more than $400 \mathrm{~m}$ in some places (Morley et al. 2009). The URF consists of thick red gypsum and salt layers that spread widely across the central and northwestern Iran, covering the deposits of the Qom Formation. In terms of lithology, the URF is similar to the LRF, and that is why both formations are described by the term Red and rather distinguished by their relative position (upper vs. lower) (Darvishzadeh 1992).

The Qom Formation exhibits poor to moderate porosity (up to $12 \%$, but generally less than 6-8\% effective porosity). Fractures are key to reservoir performance although their impact is not well quantified.

Composed mainly of limestone, the Qom Formation serve as reservoir rock in Alborz and Sarajeh fields, wherein nine wells have been drilled so far. The Alborz oil field has produced some $20 \mathrm{Mbbl}$ of oil so far. Located to the east of Qom city and the southeast of the Alborz Anticline, Sarajeh gas field hosts some 0.3 TCF of gas (Jaafari 1963; Aghanabati 2004). The Members e and $f$ of the Qom Formation are known to bear some type-II kerogen developed in a semioxidant environment. Organic carbon contents of the samples from well and surface layers have been reportedly equal to 3 and 0.6, respectively (Reports 2019). This hydrocarbon system is capped by either the lower part of the URF (composed mainly of gypsum, salt, and anhydrite) or intermediate anhydrite-dominated layers of the Qom Formation (Darvishzadeh 1992). The Alborz and Sarajeh anticlines in Qom region contain gas mainly because of their OM type (type-II kerogen), high thermal flux due to the large thickness of the salt layers beneath the anticlines, and the volcanic activities during the Cenozoic that induced the secondary destruction of gases (Morley et al. 2013). This indicates that the limestones of Qom formation worth exploring for hydrocarbons. Outcrops of the URF are well visible in parts of southern Semnan and Garmsar. The Qom Formation is further extended into the southern Semnan, suggesting the presence of reservoir zones similar to those found in Qom and Varamin, highlighting the particular importance of the study area in terms of hydrocarbon exploration.

\section{Materials and methods}

In this study, a total of 15 soil samples were collected from a depth of 1-2 m using a special tool (a hollow metal pipe) and transferred to the surface for the analysis. The samples were collected from areas surrounding the Khourian Well and nearby seepages (Fig. 3). In this study, dispersed sampling was performed to capture the distribution of macroseepage anomalies in the area near the well. Approximately 500-gr soil samples were taken in pre-sterilized whirl-pack bags under aseptic conditions from a depth of about 1-2 m and stored at $2-4{ }^{\circ} \mathrm{C}$ for microbial analysis (Rasheed et al. 2015). For geochemistry analysis, each sample was wrapped in an aluminum foil and labeled by a sample number and geographic coordinates of sampling. First round of sampling was carried out in the spring season, with a second round conducted in the autumn for further examination of the samples and comparison of $\mathrm{pH}$ values and microbial analyses results.

\section{Geochemical procedure}

The samples were subjected to Rock-Eval analysis to determine the state of OM content in the study area (Table 1). For this purpose, soil samples taken from areas near the seepages were studied in terms of hydrocarbon potential. Accordingly, $100 \mathrm{mg}$ of each sample was prepared and evaluated on a Standard Rock-Eval 6 pyrolysis machine manufactured by the Vinci Technologies. In this thermally regulated method, the sample was powdered and homogenized before placing it in a small capsule and subjecting the capsule to two stages of pyrolysis and oxidation (Saberi et al. 2016).

Stable isotope analyses were carried out on a Finnigan Delta Plus mass spectrometer. The stable sulfur isotope data were presented in $\delta$ notation relative to the V-PDB standard (Sechman et al. 2013). To measure this parameter, the sample was studied for a particular isotope of sulfur (here $\delta^{34} S$ ), returning a value of -0.4 .

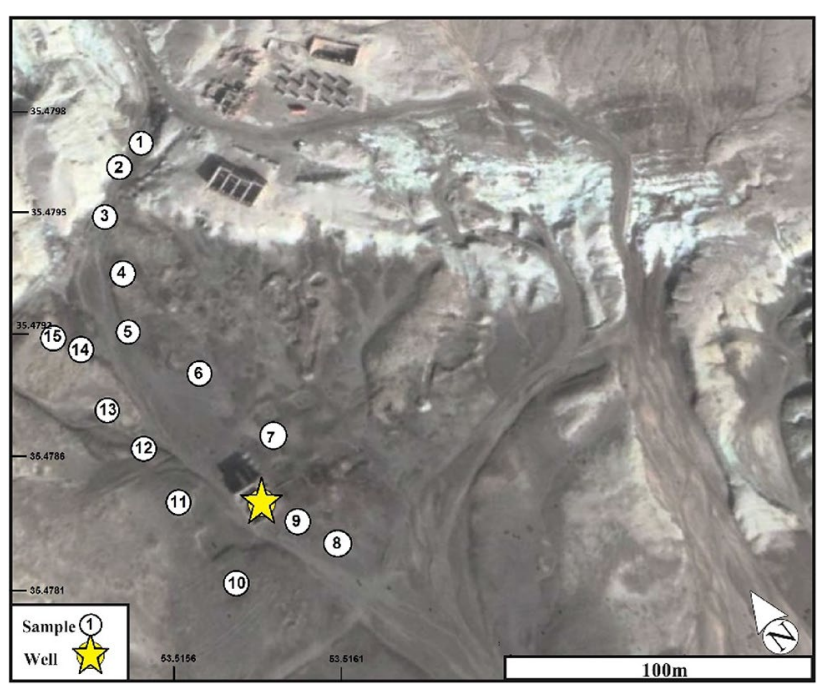

Fig. 3 Location map of Khourian Well and sampling points

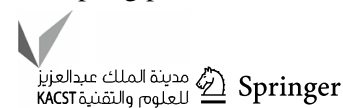


Table 1 Summary of the results of Rock-Eval pyrolysis

\begin{tabular}{lllllllll}
\hline Sample & $\mathrm{S}_{1}(\mathrm{mg} / \mathrm{g})$ & $\mathrm{S}_{2}(\mathrm{mg} / \mathrm{g})$ & $\mathrm{S}_{1}+\mathrm{S}_{2}$ & $\mathrm{PI}$ & $\mathrm{HI}$ & TOC $(\%)$ & OI & MIN C (\%) \\
\hline 1 & 0.07 & 2.16 & 2.23 & 0.03 & 267 & 0.81 & 305 & 0.63 \\
2 & 0.19 & 9.29 & 9.48 & 0.02 & 378 & 2.46 & 210 & 3.04 \\
3 & 21.2 & 3.85 & 25.05 & 0.85 & 158 & 2.43 & 240 & 8.93 \\
4 & 23.04 & 7.26 & 30.3 & 0.76 & 229 & 3.17 & 214 & 8.22 \\
5 & 21.85 & 4.28 & 26.13 & 0.84 & 169 & 2.54 & 192 & 9.1 \\
6 & 25.93 & 12.67 & 38.6 & 0.67 & 307 & 4.13 & 321 & 6.41 \\
7 & 27.35 & 9.71 & 37.06 & 0.74 & 255 & 3.81 & 354 & 6.43 \\
8 & 25.2 & 8.54 & 33.74 & 0.75 & 248 & 3.45 & 287 & 6.88 \\
9 & 3.23 & 2 & 5.23 & 0.62 & 202 & 0.99 & 189 & 6.45 \\
10 & 0.05 & 0.32 & 0.37 & 0.15 & 89 & 0.36 & 275 & 0.57 \\
11 & 0.29 & 2.59 & 2.88 & 0.1 & 157 & 1.65 & 177 & 0.26 \\
12 & 0.29 & 3.14 & 3.43 & 0.08 & 240 & 2.65 & 193 & 0.19 \\
13 & 0.1 & 0.28 & 0.38 & 0.26 & 82 & 0.34 & 224 & 3.7 \\
14 & 0.35 & 0.46 & 0.81 & 0.43 & 87 & 0.53 & 250 & 4.85 \\
15 & 0.06 & 0.19 & 0.25 & 0.24 & 61 & 0.31 & 189 & 3.48 \\
\hline
\end{tabular}

\section{Indirect surface geochemistry: in-lab measurements}

\section{Isolation of hydrocarbon-oxidizing bacteria}

The soil samples collected from the study area were analyzed for the hydrocarbon-oxidizing bacteria. For this purpose, the bacteria were isolated in an atmosphere of propane or, in some cases, $n$-butane using a culture enrichment technique, and measurement of the bacteria was taken by the standard plate count (SPC) method. The procedure began with dissolving $1 \mathrm{~g}$ of a soil sample in $9 \mathrm{~mL}$ of sterilized water to prepare a stock solution, which was further diluted to 5-10 dilutions. Next, $0.1 \mathrm{~mL}$ of the prepared solution was added to a mineral salt medium (MSM) together with $1000 \mathrm{~mL}$ of distilled water at $\mathrm{pH} 7$ in petri dishes (Atlas 2010). The sample was then placed in a glass plates, which was filled by propane $/ n$-butane and neutral air (hydrocarbonfree atmospheric gas) at a 1:1 ratio. These plates were then incubated at $35 \pm 2{ }^{\circ} \mathrm{C}$ for 10 days. After incubation, colonies of hydrocarbon-oxidizing bacteria were counted manually and reported in cfu/g of soil samplem. This was done by capturing images of the sample using a stereoscope and making use of MIP software.

\section{Laboratory analyses of calcium carbonate, pH evolution, and magnetic susceptibility of soil samples}

Calcium carbonate (calcite) contents of the samples were determined using X-ray diffraction (XRD) analysis, which is usually used for general identification of different minerals comprising a sample. The results of the XRD analyses are shown in Fig. 4.

To determine the soil $\mathrm{pH}$, a watery mud was prepared by mixing $50 \mathrm{~g}$ of the soil sample with $50 \mathrm{~mL}$ of distilled water and stirring the mixture for $1 \mathrm{~h}$. The $\mathrm{pH}$ of the mix was measured at $24^{\circ} \mathrm{C}$ (Rabbani 2017). The results of this analysis are reported in Table 2. In order to further capture the possible effect of the environmental conditions, sampling was done in two seasons, namely the spring and the autumn, when the $\mathrm{pH}$ of the sample was about 6.3 at $24{ }^{\circ} \mathrm{C}$. The difference in $\mathrm{pH}$ value between the samples taken in the spring and the autumn was found not to impose any significant effect on the oxidation of soil, with a large share of such difference being related to the variations of temperature, soil moisture, and precipitation across the study area.

The soil samples were subsequently subjected to magnetic susceptibility measurements. For this purpose, the sample was grinded in a mortar and then dried at room temperature. In this work, the iron ion parameter was measured using an atomic absorption spectrometer. Before the analysis, the soil samples were prepared using the fouracid digestion method. To do this, $0.5 \mathrm{~g}$ of dry sample was exposed to $2.5 \mathrm{~mL}$ of concentrated nitric acid in a Teflon bush and the mix was left at room temperature for $30 \mathrm{~min}$. Then, $5 \mathrm{~mL}$ of perchloric acid and $1 \mathrm{~mL}$ of concentrated hydrofluoric acid were added to the mix and the vessel was heated up to $100{ }^{\circ} \mathrm{C}$. Given the aim of complete digestion of the solid sample, the addition of hydrofluoric acid to the sample continued until a clear mix was obtained. In a final stage, another $5 \mathrm{~mL}$ of concentrated hydrochloric acid was introduced to the vessel and it was heated up to $100{ }^{\circ} \mathrm{C}$ for $10 \mathrm{~min}$. Once cooled, the sample was transferred to a $50-\mathrm{mL}$ volumetric balloon that was preloaded with $50 \mathrm{~mL}$ of deionized water (Eaton et al. 1998). The result of this analysis is shown in Fig. 5. 
Fig. 4 Results of XRD analysis

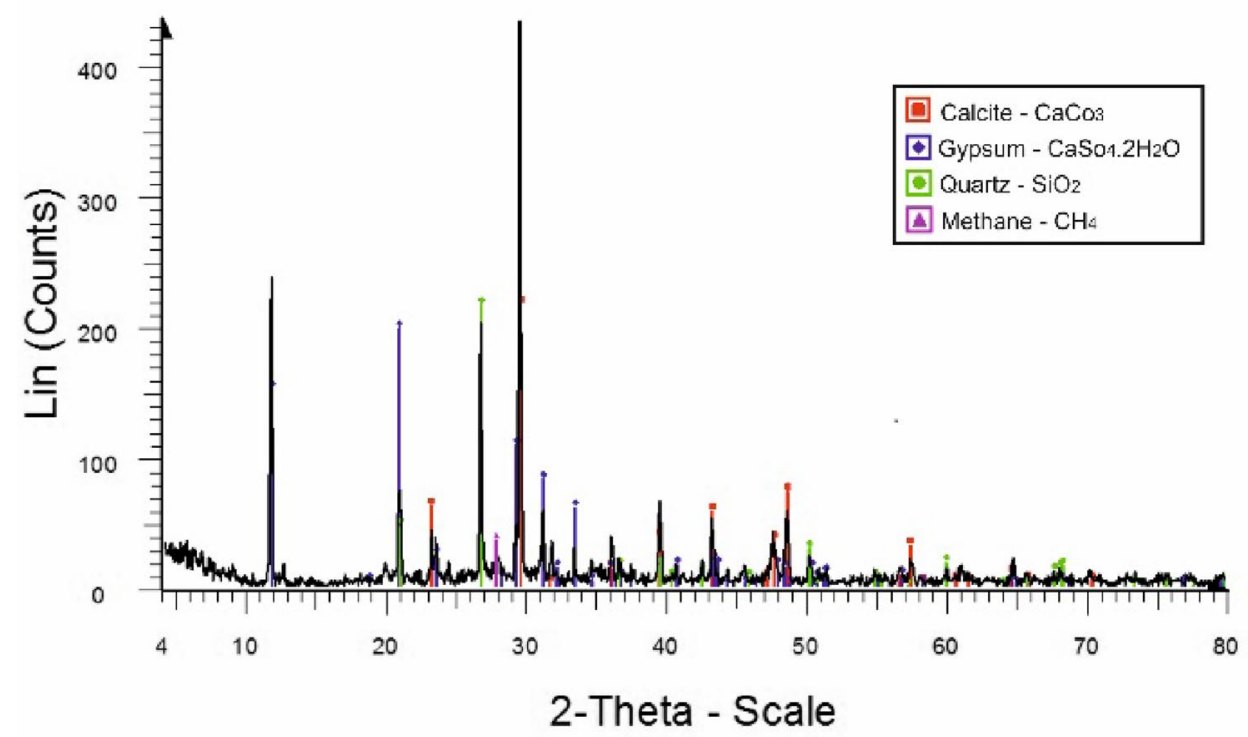

Table $2 \mathrm{pH}$ values of the samples taken in the spring at $24{ }^{\circ} \mathrm{C}$

\begin{tabular}{llllllllllllllll}
\hline Sample & 1 & 2 & 3 & 4 & 5 & 6 & 7 & 8 & 9 & 10 & 11 & 12 & 13 & 14 & 15 \\
\hline $\mathrm{pH}$ & 7.8 & 6.6 & 7.7 & 4.9 & 7.5 & 7.8 & 8 & 8 & 7.8 & 7.9 & 7.9 & 7.3 & 7.6 & 5.4 & 7.5 \\
\hline
\end{tabular}

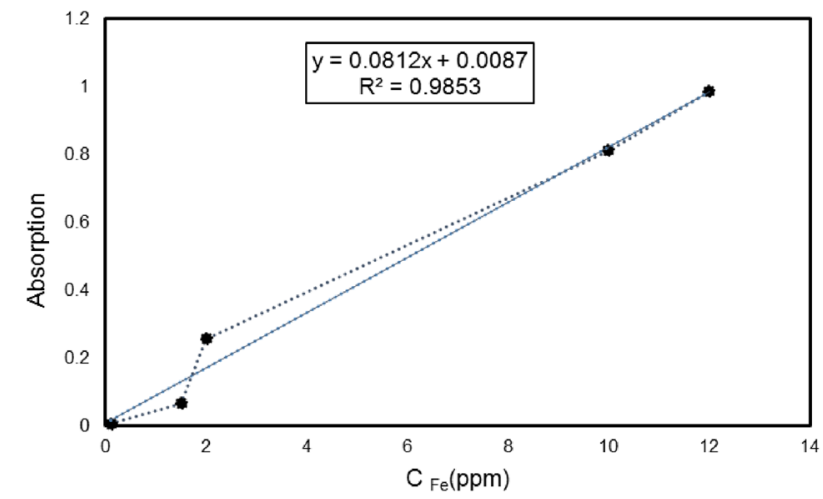

Fig. 5 Results of the atomic absorption analysis

\section{Results and discussion}

The OM content of a rock sample is usually measured as total organic carbon content (TOC), expressed as a percentile of the dry rock. The TOC exhibited variations in the range of $0.31-4.13 \mathrm{wt} . \%$ across the study area. Some samples showed TOCs in the range of 0.31-1.65 wt.\%, which was very poor as their TOC was a result of weathering and non-oxidizing agents (Fig. 6).

According to the data presented in Table 1, the minimum and maximum amounts of free hydrocarbon $\left(S_{1}\right)$ were found to be $0.05 \mathrm{mg} \mathrm{HC} / \mathrm{g}$ of rock (Sample 10) and $27.35 \mathrm{mg} \mathrm{HC} / \mathrm{g}$ of rock (Sample 7), respectively. Average

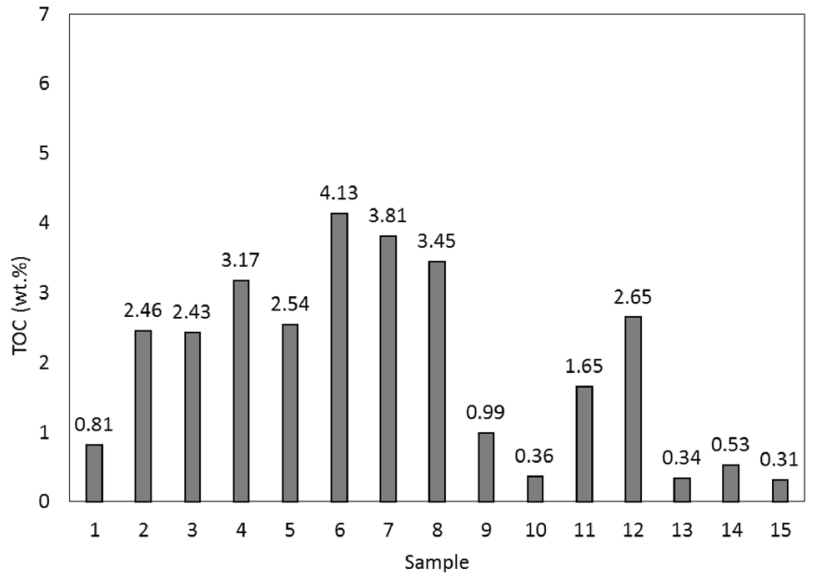

Fig. 6 Histogram of TOC values

value of this parameter over the samples was $9.95 \mathrm{mg}$ $\mathrm{HC} / \mathrm{g}$ of rock. Moreover, the minimum and maximum hydrocarbon generation potentials $\left(\mathrm{S}_{2}\right)$ were found to be $0.19 \mathrm{mg} \mathrm{HC} / \mathrm{g}$ of rock (Sample 15) and $12.67 \mathrm{mg} \mathrm{HC} / \mathrm{g}$ of rock (Sample 6), respectively, with an average of $4.45 \mathrm{mg}$ $\mathrm{HC} / \mathrm{g}$ of rock over all samples. The lowest $(0.31 \mathrm{wt} . \%)$ and highest (4.13 wt.\%) levels of TOC were seen for Samples 15 and 6, respectively, with an average TOC 1.97 wt.\% over all studied samples.

The results of Rock-Eval pyrolyses were further plotted in the form of anomalies using Golden Surfer 14.0. The graph shows anomalous TOC values near the seepage 
(with significantly higher values than the other points) (Fig. 7a). According to Table 3 and Fig. 7a, some of the samples were recognized as impregnated with hydrocarbons, suggesting the nonindigenous nature of these hydrocarbons that might originate from the underlying layers.

As shown in Fig. $7 \mathrm{~b}$, the Samples 3 to 8 exhibited higher $S_{1}$ values, indicating a large outflow of hydrocarbons from subsurface sources in this area. It could further be an indication of the accumulation of hydrocarbon resources in this area.

In contrast to TOC, the parameter $S_{1}$ some technical terms about the origin of the OM in the soil. In this study, a crossplot of $S_{1}$ against TOC was used to ensure that the samples were not contaminated or impart any hydrocarbon substances (Fig. 8). Indeed, a high value of $\mathrm{S}_{1}$ in combination with a small TOC might indicate hydrocarbon migration. In the present work, Samples 3 to 9 were found to be nonindigenous fragments of Qom Formation that were probably detached due to leakage in the cap rock. The significantly higher value of $S_{1}$ than $S_{2}$ in Samples 4, 6, 7 , and 8 suggested some anomalous TOC within the area, with other findings of the Rock-Eval pyrolysis revealing that these samples were impregnated with hydrocarbons as the hydrocarbons had migrated from subsurface to the surface of the Earth. As explained in the geological setting, the Qom Formation has served as source rock, reservoir rock and cap rock in Central Iran Basin (CIB). In this area, geochemical surveys were carried out on free hydrocarbons that leaked from the seepages, and the amounts of

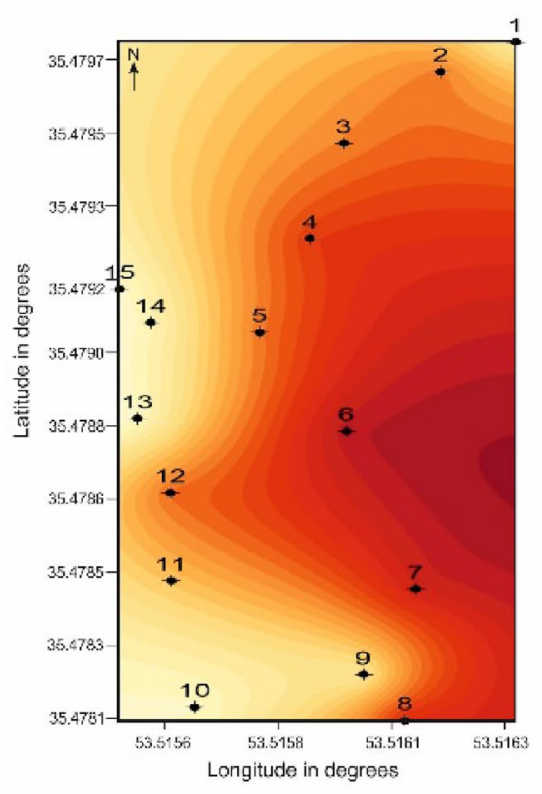

TOC $(\%)$

a
Table 3 Results of counting hydrocarbon-oxidizing bacteria (cfu/g of dry soil)

\begin{tabular}{llllll}
\hline Dilution & $10^{-1}$ & $10^{-2}$ & $10^{-3}$ & $10^{-4}$ & $10^{-5}$ \\
\hline Test \#1 & $1.05 \times 10^{4}$ & $2.7 \times 10^{5}$ & $6.5 \times 10^{5}$ & - & - \\
Test \#2 & $9.1 \times 10^{3}$ & $1.4 \times 10^{5}$ & $1.1 \times 10^{6}$ & $9.6 \times 10^{6}$ & $9.8 \times 10^{7}$ \\
\hline
\end{tabular}

free hydrocarbons (S1, S2) and total organic carbon (TOC) have been reported.

The varying amount of free hydrocarbons in the seepages of Khourian Desert, as determined per the results of the Rock-Eval pyrolysis, strongly justified the presence of hydrocarbon-oxidizing bacteria in the study area. Being able to utilize propane or $n$-butane as a carbon source, the bacteria were merely developed as bacterial colonies on the MSM plates. Control plates were incubated similarly but without $n$-pentane and $n$-hexane. After culturing the soil and water samples, the bacteria were seen to develop under hydrocarbon gas in the incubation condition. Then, microscopic images were taken from the plates containing the hydrocarbon-oxidizing bacteria (Fig. 9). In test \#1, which was performed at a dilution in the range of $10^{-4}-10^{-5}$, the lower amount of hydrocarbons in the samples due to the dilution and also the effect of soil salinity prevented the growth of the bacterial colonies. MIP software was used to measure the bacteria in cfu/g of soil sample (Figs. 9 and 10). The results of statistical analysis of the hydrocarbon-oxidizing bacteria are given in Table 3.

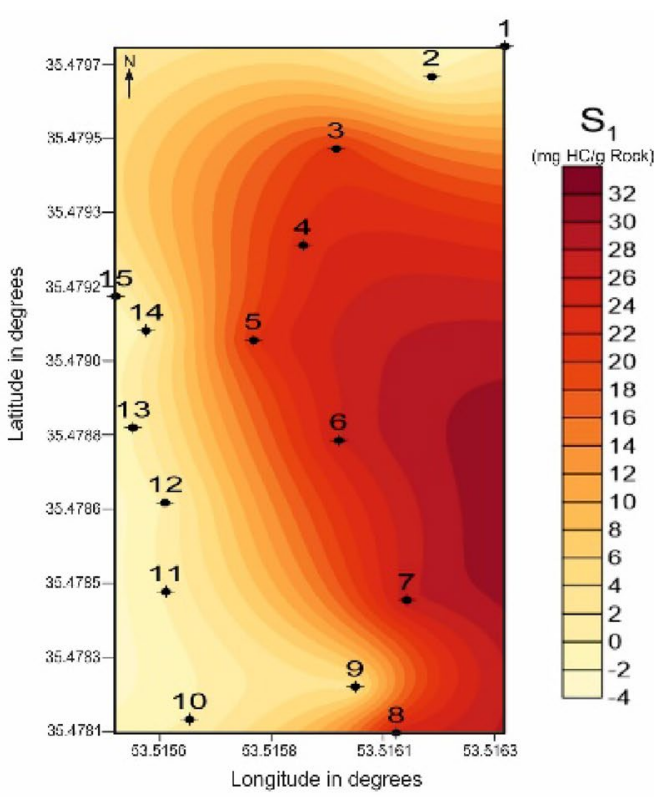

b

Fig. 7 Maps of a TOC and $\mathbf{b}$ free hydrocarbon content $\left(\mathrm{S}_{1}\right)$ across the study 
Fig. 8 Crossplot of $S_{1}$ against TOC (Hunt 1996)

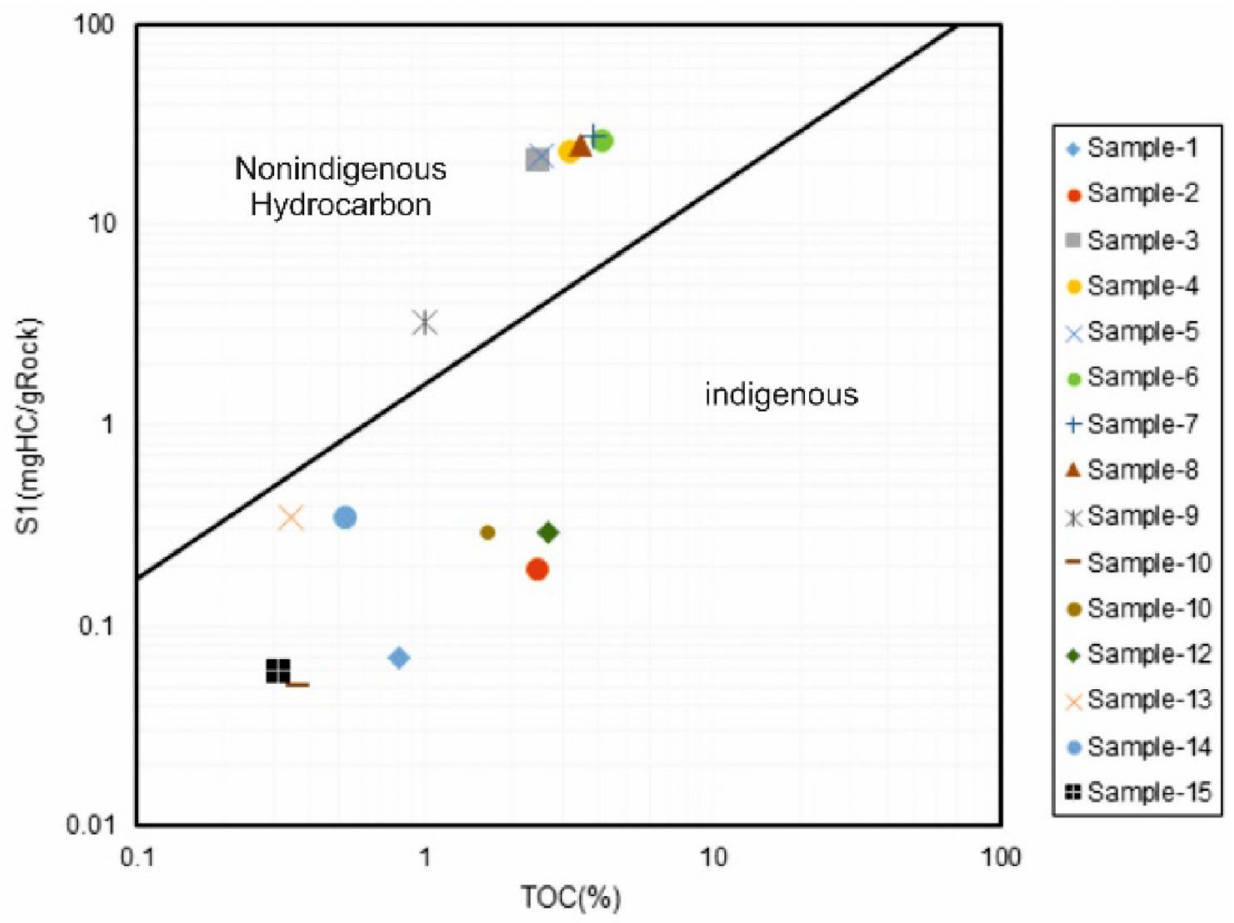

The possibility of detecting an oil or gas field using the microbial analysis method presented in this study is emphasized by the fact that the count of hydrocarbon-oxidizing bacteria in the soil or sedimentary samples is relatively low. According to studies conducted in different parts of the world, if this number lies, depending on the ecological conditions, between $10^{3}$ and $10^{4} \mathrm{cfu} / \mathrm{g}$ of the soil in the vicinity of a hydrocarbon micro-seepage, the concentration of adsorbed gases from the environment would be reduced due to the use of oxidizing hydrocarbon bacteria (Wagner et al. 2002; Rasheed et al. 2012c). In the present study, on average, the samples showed a hydrocarbon-oxidizing bacterial count of $1.22 \times 10^{6} \mathrm{cfu} / \mathrm{g}$ of soil sample, which is significant and thereby substantiate the seepage of significant hydrocarbon accumulations from the subsurface. In other words, the bacteria grow rapidly when they are provided with the required nutrient in the medium. Accordingly, one can consider the count of bacterial colonies at points above the hydrocarbon reservoir, where some hydrocarbon has reached the surface due through migration. That is to say, the number and activity of microorganisms increases with the extension of respective oilfield.

By reviewing and comparing Fig. 9a with an image presented in the article by Whittenbury et al. (1970) it was found that the bacteria grew in this test belongs to the Methylocystis parvus species. Figure 10a shows another bacteria belonging to the Methylomonas streptobacterium species (Whittenbury et al. 1970).

In test \#1, the XRD results showed that the exposure of Sample 7 to methane promoted the growth and dispersion of the bacteria in the sample upon further providing the sample with a nutrient-abindant medium containing salt and agar. Also, upon oxidization of methane inside the soil, colonies of Methylocystis parvus grew, according to the pattern matching results. One could also analyze the $\mathrm{pH}$ and oxidation conditions under the presence of hydrocarbons on the surface based on XRD patterns and the absence/presence of hydrocarbon-oxidizing bacteria in the rocks composed of, for example, kaolin and montmorillonite. In this respect, the presence of methane and other hydrocarbons together with the severity of the symptoms could indicate the presence thermogenic gas with oil or capping of the oil reservoir.

Acknowledging its higher $S_{1}$ value than other samples, Sample 7 was subjected to further XRD analysis to determine the type of minerals in the region. Accordingly, the most probable location in terms of hydrocarbon accumulation potential was found to be within the vicinity of the well. The results of the XRD analysis on Sample 7 are shown in Table 4.

On the XRD pattern, Sample 7 was identified in terms of its calcite, gypsum, and quartz contents. As mentioned previously, the URF is dominated by calcite and gypsum. Also, the presence of methane, as per the XRD analysis results, and the high percentage of free hydrocarbons in this sample verified the presence of hydrocarbon in this sample. The Rock-Eval pyrolysis results further highlighted the presence of large amount of free hydrocarbons in the sample. The presence of gypsum and salt domes in this region boosted the chances of alteration of clay minerals to calcite as the hydrocarbon migrated from the subsurface to

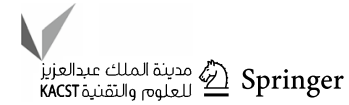


Fig. 9 Results of test \#1 at a dilution of $\mathbf{a} 10^{-1}$, b $10^{-2}$, and c $10^{-3}$

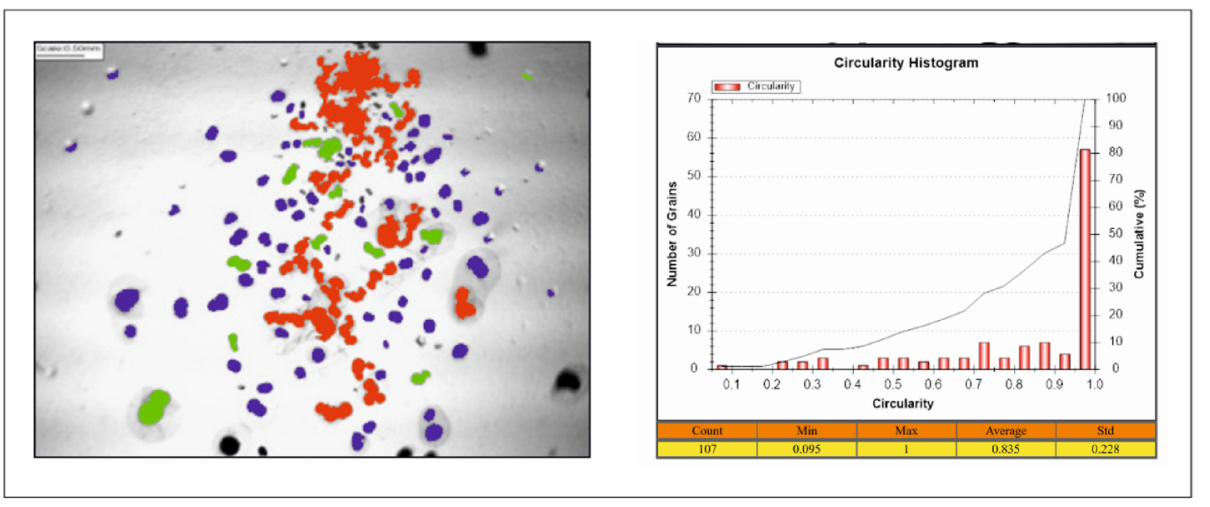

a

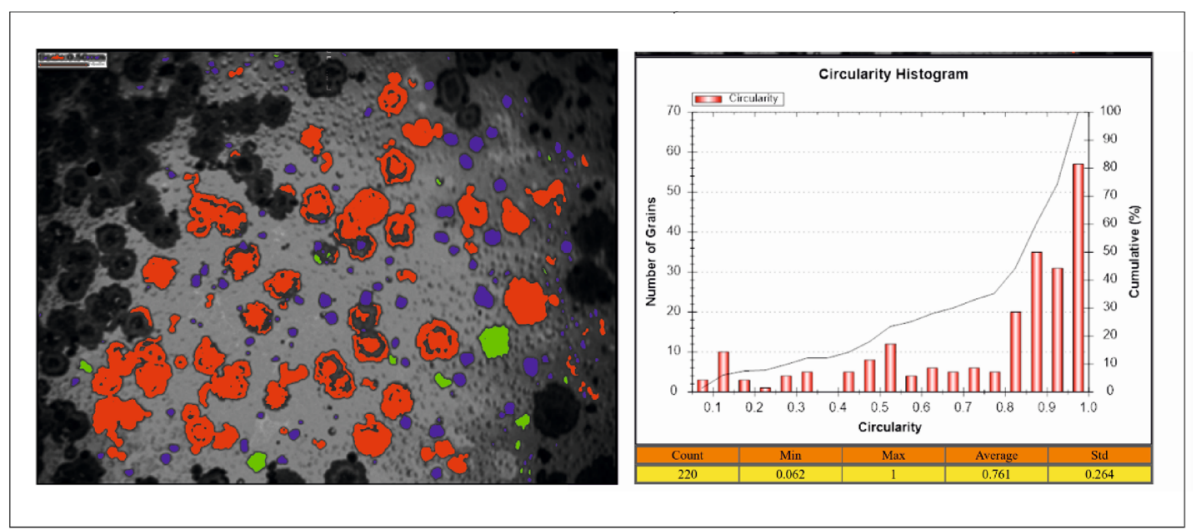

b

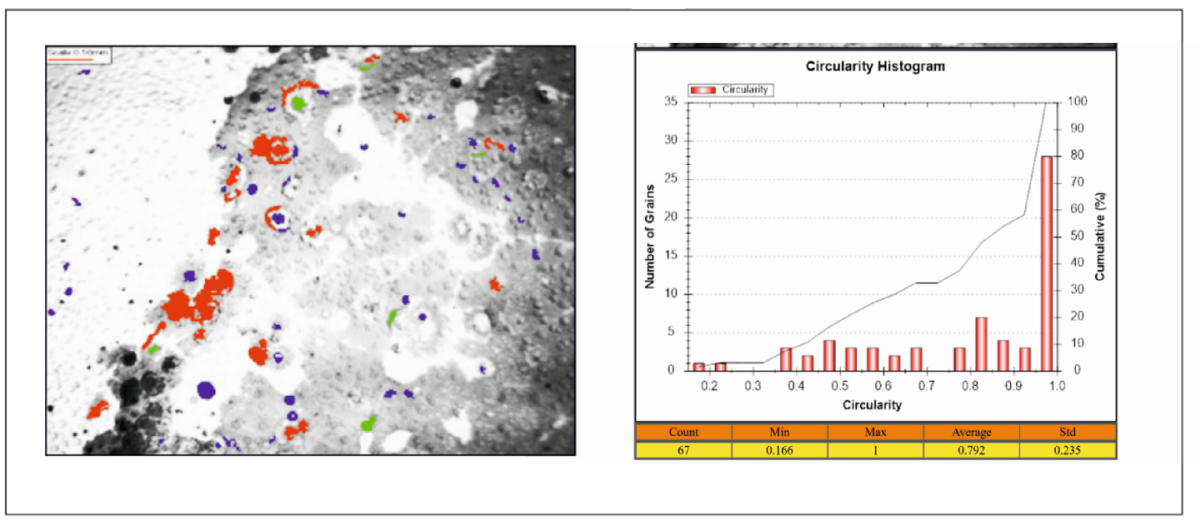

C the earth surface. In fact, the occurrence of oxidation during the migration produced some carbon dioxide that was later on dissolved in underground water to form calite with the calcium content of water. These near-surface diagenetic carbonates were principally formed as a byproduct of the oxidation of hydrocarbons (methane in particular). Carbon dioxide is known to evolve and react with water to produce bicarbonate. This bicarbonate then forms some bonds with calcium and magnesium in the underground water and precipitates as carbonate or carbonate cement with an isotopic signature matching that of the parent hydrocarbon (Yang et al. 2000) (Fig. 11).

Our investigations indicated the presence of $1 \mathrm{ppm}$ of iron ion in Sample 7. The presence of iron ion was boosted by the presence of calcite in different layers. Increased amounts of iron minerals was found in higher horizons. Usually altered 
Fig. 10 Results of test \#2 at a dilution of $\mathbf{a} 10^{-1}, \mathbf{b} 10^{-2}$, and c $10^{-3}$

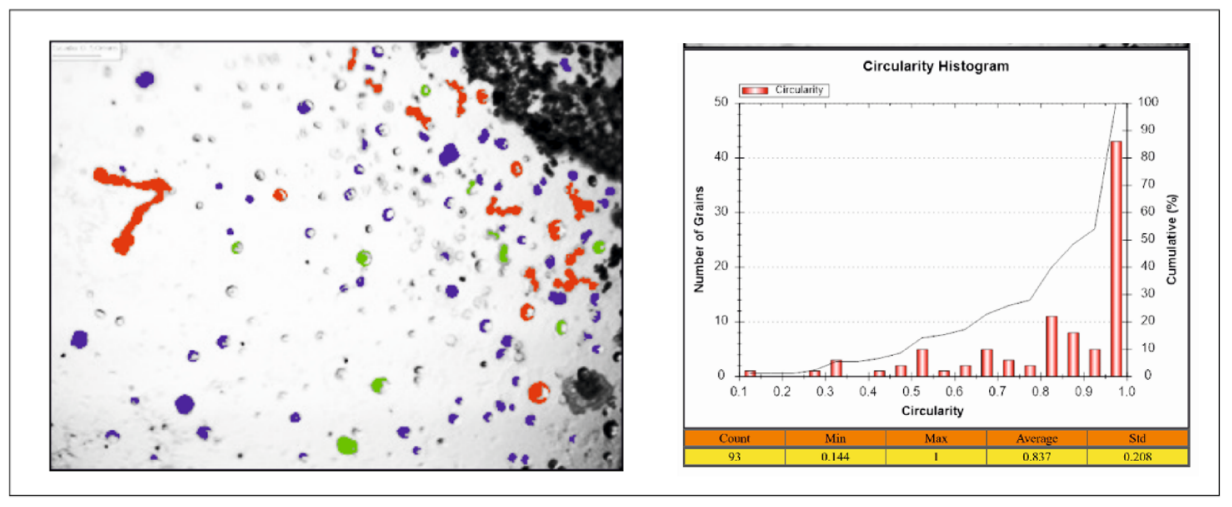

a

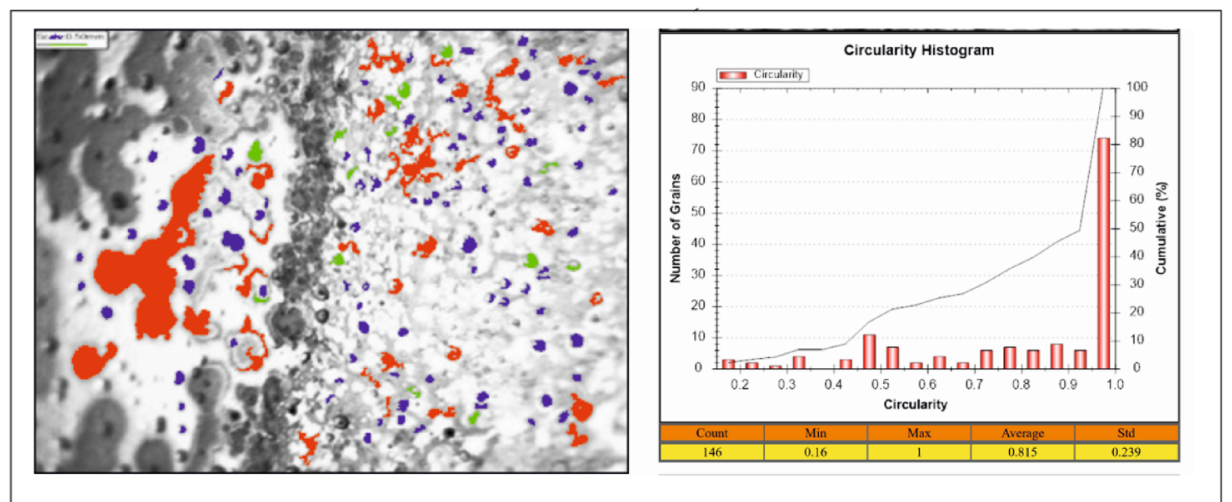

b

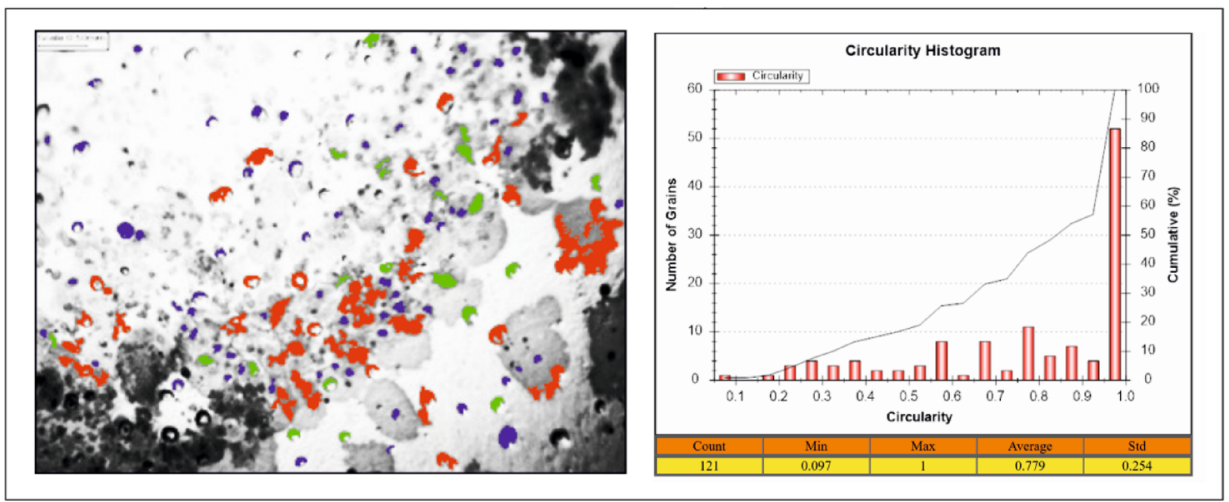

C

Red area: Methylocystis parvus and Methylomonas streptobacterium Green area: Methylobacter chroococcum

Blue area: Methylococcus minimu

Black area: Methylobacter chroococcum
Table 4 Minerals identified in Sample 7

\begin{tabular}{lll}
\hline Chemical formula & Mass range & Mineral phase \\
\hline $\mathrm{CaCO}_{3}$ & $26 \%$ & Calcite \\
$\mathrm{CaSO}_{4} \cdot 2 \mathrm{H}_{2} \mathrm{O}$ & $37 \%$ & Gypsum \\
$\mathrm{SiO}_{2}$ & $34 \%$ & Quartz \\
$\mathrm{CH}_{4}$ & $3 \%$ & Methane \\
\hline
\end{tabular}

by oxidation on the surface, the iron ions are commonly found together with carbon, oxygen, and sulfur.

As mentioned earlier, the gypsum and anhydrite strata are replaced with carbonate in the cap rock (salt domes), forming the so-called Gach-i-turush as a result of chemical reactions between petroleum products. The Gach-i-turush exists actively across the region. The absence of reservoir gas on the surface has prevented any heat from the exhaust 
Fig. 11 Variations of surface alterations caused by hydrocarbon micro-seeping from the reservoir (modified after (Chen et al. 2017))

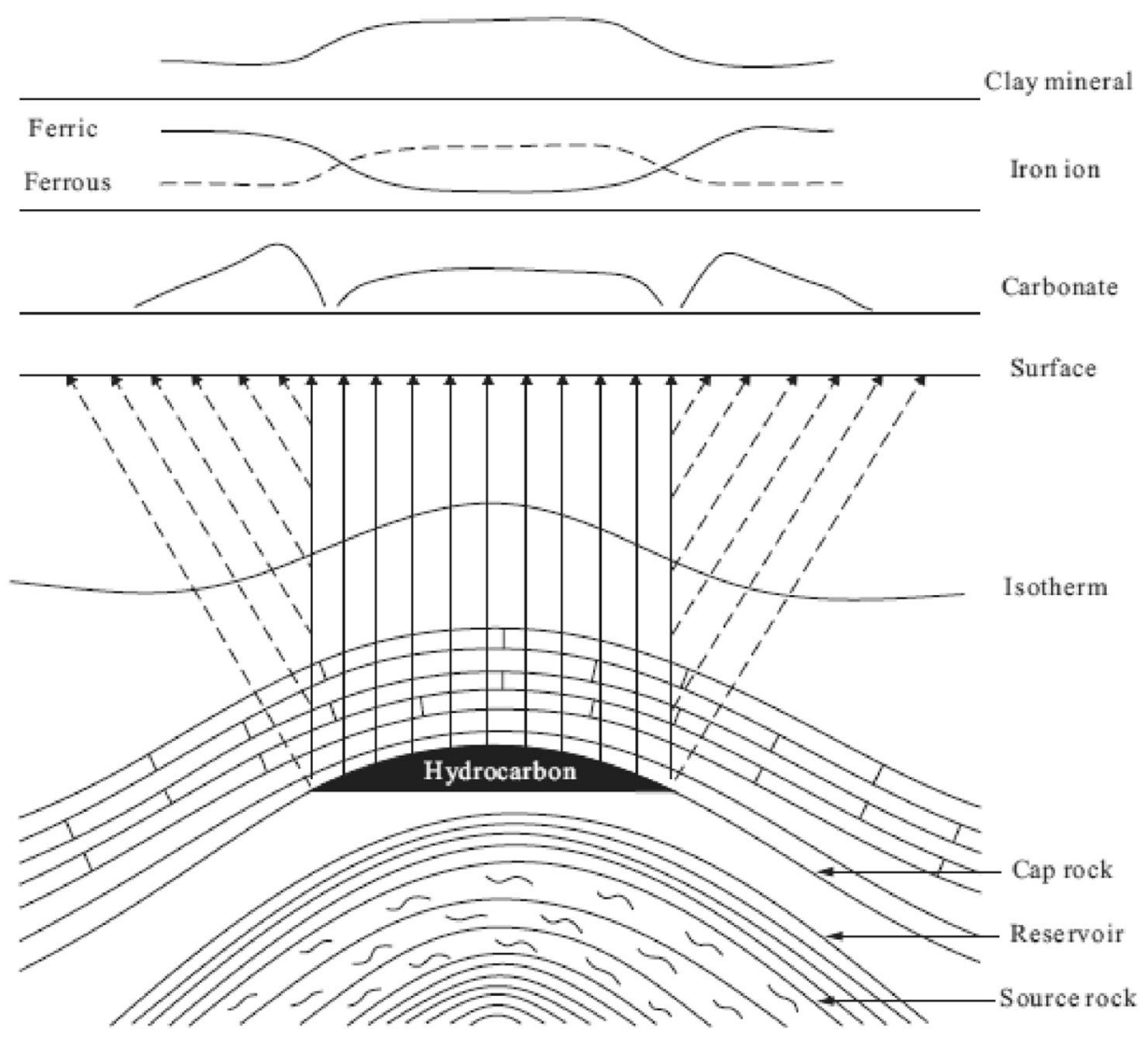

gas though there are sulfur crystals with bitumen affinity in the vicinity of the gas evacuation hole.

As stated above, the samples taken from Khourian Well contained some Gach-i-turush. According to Hunt, organic samples are likely to contain $7.5 \%$ to $-25 \%$ sulfur isotope. In this study, the amount of sulfur isotope was found to be $-0.4 \%$, which is in the range presented by Hunt for organic origin of the samples. Therefore, the Gach-i-turush in this area has an organic origin, indicating the presence of hydrocarbon in subsurface reservoirs. Figure 12 specifies different sources of sulfur. During the progradation of the sea into the CIB, sedimentation of the sulfur-bearing Qom Formation in the seawater occurred concurrently with the sedimentation of the OM, when the reduction of the bacteria into hydrogen sulfide and high reactivity of the OM provided for the formation of sulfur-carbon bonding and the entry of sulfur into the OM structure. The intervals indicated in Fig. 12 prove that the isotopes obtained from the rocks of this region are in the range of neither igneous rocks nor coal deposits.

Another important parameter analyzed in this study is the $\mathrm{pH}$ value of the samples. To compare the results obtained from the $\mathrm{pH}$ analysis, a potential map is plotted in Fig. 13. Comparing this figure to that of $S_{1}$ (Fig. 7b), it can be found that Sample 4 exhibits the highest potentials for hydrocarbon exploration due to the increase in $\mathrm{S}_{1}$ and decrease in $\mathrm{pH}$

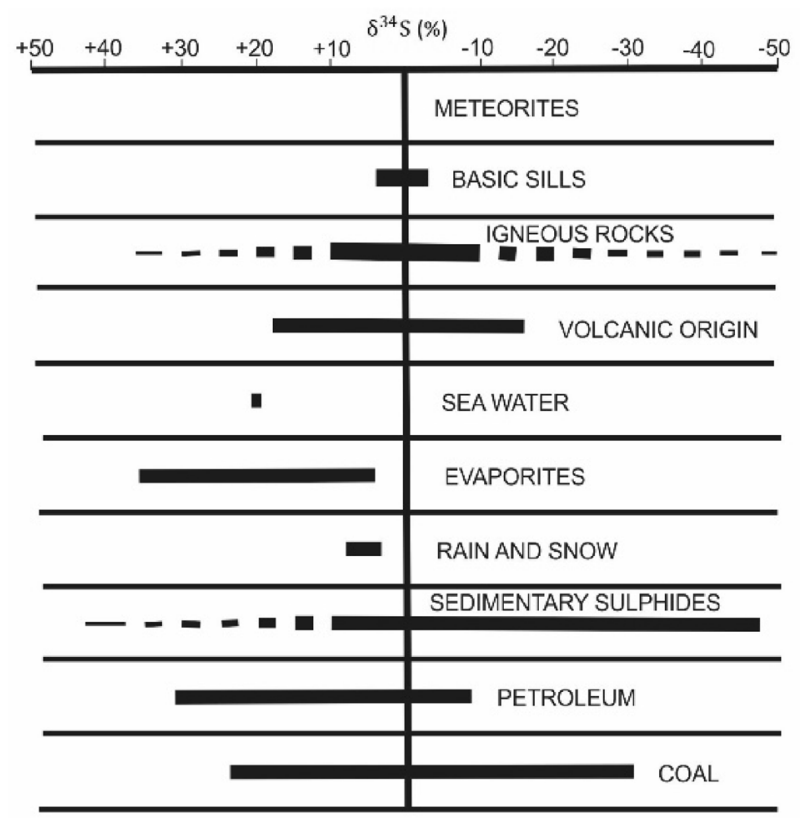

Fig. 12 Distribution of sulfur isotope in the nature (modified after (Thode 1991)) 


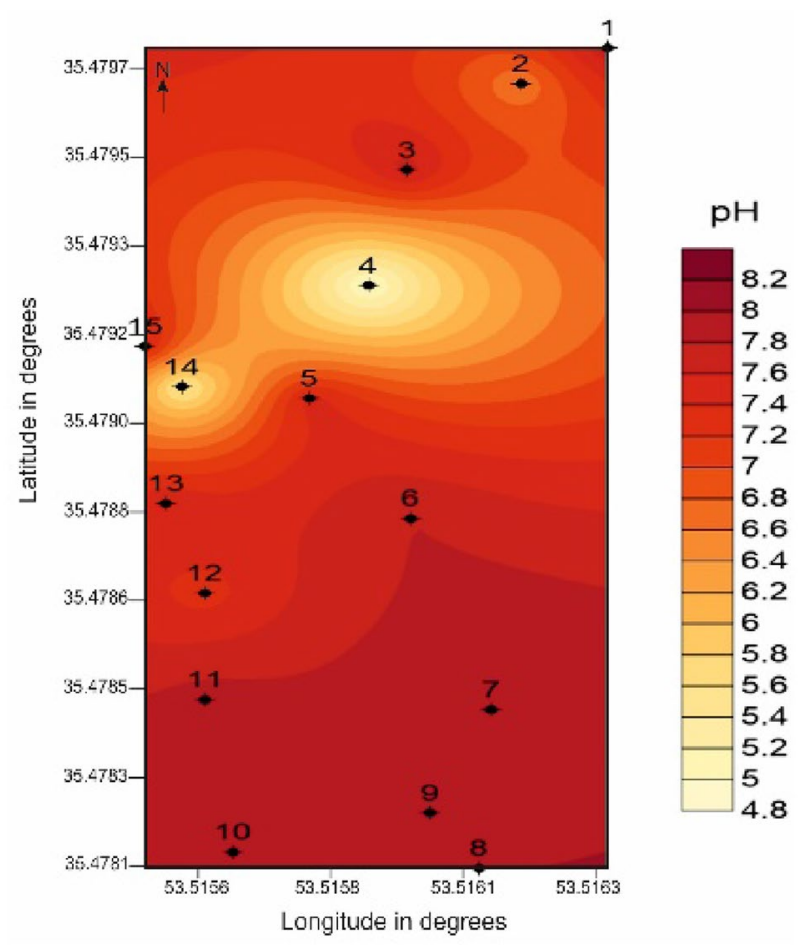

Fig. $13 \mathrm{pH}$ analysis map of the study area

value, shedding light to the presence of hydrocarbon in the study area. The decrease in the $\mathrm{pH}$ value could be linked to the increase in the amount of hydrocarbon released from subterranean layers to the oil fountain.

Considering the lithology of the region (discussed in an earlier section) and the presence of calcite and gypsum in the oxidation environment, there were chances that the chemical reaction between hydrocarbon and evaporative minerals leads to the formation of Gach-i-turush. The presence of iron ion in the prepared solution (about $1 \mathrm{ppm}$ ) could further indicate the presence of hydrocarbon sources in the study area. The migration and leakage of hydrocarbons in this area decreased the $\mathrm{pH}$ of the environment. Iron is usually accompanied with carbon, oxygen and sulfur. Precipitation of metallic oxides (e.g., iron oxides and iron sulfides) tends to change the soil. The oxidative condition established across the region and the presence of sulfur caused significant precipitation of the iron ions, marking the presence of hydrocarbon sources that had penetrated up to the surface.

\section{Conclusions}

In this research, 15 samples of the Khourian Desert were studied through surface geochemistry, with a focus on the evolution of the rock and fluid throughout the migration of hydrocarbons to the surface, to evaluate their hydrocarbon potentials. We aimed at evaluating the hydrocarbon exploration potential of the region by performing Rock-Eval pyrolysis, sulfur isotope analysis, study of hydrocarbonoxidizing bacteria, and surface secondary changes assessment (e.g., changes in calcium carbonate volume, $\mathrm{pH}$ and magnetic susceptibility).

Variation of the free hydrocarbon content $\left(\mathrm{S}_{1}\right)$ in different parts of the study area (as per the results of Rock-Eval pyrolysis) was evident, and significant amounts of hydrocarbon-oxidizing bacteria were detected in the samples. On average, the samples contained $1.22 \times 10^{6} \mathrm{cfu}$ of bacteria per gram of soil sample. Migration and leakage of hydrocarbons across the study area led to the dispersion of TOC values from the pyrolysis analysis, secondary changes to mineral composition and magnetic susceptibility of the soils, and reduced $\mathrm{pH}$ of the environment. The sulfur isotope $\left(\delta^{34} S\right)$ measurements were taken to investigate the origin of sulfur and Gach-i-turush. Microbial studies revealed the presence of light hydrocarbondegrading bacteria that consume light hydrocarbons line propane or butane.

The results of surface geochemical studies in this area indicated the surface-presence of hydrocarbons from underground sources and their migration to the surface through fractures in the cap rock, changing the surface. Secondary changes to the surface soil and sediments (increased concentrations of calcium carbonate, iron, and sulfur and reduced $\mathrm{pH}$ value) and the presence hydrocarbon-oxidizing bacteria are good evidence for a correlation between the free hydrocarbons and the subsurface reservoir. A possible explanation for the presence of free hydrocarbons on the surface is the presence of a gas reservoir in the nearby area (Qom Formation). As the time passed and the free hydrocarbons went through the local cap rock (i.e. Qom Formation and URF), micro- and macro-seepages were found in the Khourian Desert. The preliminary surface geochemistry studies represent an initial first step toward studying hydrocarbon resources in the Khourian Desert. This calls for further exploration studies including geophysical surveys, geological field efforts, and drilling.

Funding In this research, financial fund has not been used and the research has been done independently.

Open Access This article is licensed under a Creative Commons Attribution 4.0 International License, which permits use, sharing, adaptation, distribution and reproduction in any medium or format, as long as you give appropriate credit to the original author(s) and the source, provide a link to the Creative Commons licence, and indicate if changes were made. The images or other third party material in this article are included in the article's Creative Commons licence, unless indicated otherwise in a credit line to the material. If material is not included in the article's Creative Commons licence and your intended use is not permitted by statutory regulation or exceeds the permitted use, you will 
need to obtain permission directly from the copyright holder. To view a copy of this licence, visit http://creativecommons.org/licenses/by/4.0/.

\section{References}

Abdullahzadeh M (1995) The Kavīr-i Khūriān oil concession. Iran 33(1):161-164

Aghanabati A (2004) The geology of Iran. Geological Survey of Iran, Tehran, p 586 (in Persian)

Atlas RM (2010) Handbook of microbiological media. CRC Press, Boca Raton,. https://doi.org/10.1201/9781420039726

Baum M, Schmitt M, Wagner M, Westerlage C (2008) Geochemical and microbiological surface investigation in northern Germany indicates interesting hydrocarbon potential. Oil Gas Euro Magaz 34(1):10. https://www.scopus.com/record/display.uri?eid=2-s2.041149150908\&origin=inward

Berberian M (1983) The southern Caspian: a compressional depression floored by a trapped, modified oceanic crust. Can J Earth Sci 20(2):163-183. https://doi.org/10.1139/e83-015

Bin Z, Meiyin D (2010) Geological setting of Garmsar block, Iran. In: 2010 International conference on challenges in environmental science and computer engineering. IEEE. https://doi.org/10.1109/ CESCE.2010.172

Chen S, Zhao Y, Zhao L, Liu Y, Zhou C (2017) Hydrocarbon microseepage detection by altered minerals mapping from airborne hyper-spectral data in Xifeng Oilfield, China. J Earth Sci 28:656665. https://doi.org/10.1007/s12583-015-0604-1

Darvishzadeh A (1991) Geology of Iran. Neda Publication, Tehran, p 901 (in Persian)

Eaton AD, Clesceri LS, Greenberg AE, Franson MAH (1998) Standard methods for the examination of water and wastewater. Am Public Health Assoc 1015:49-51

Gansser An (1955) 2 New aspects of the geology in Central Iran (Iran). In: 4th World Petroleum Congress. World Petroleum Congress.

Ghorbani M (2013) A summary of geology of Iran. In The Economic Geology of Iran. Springer, Cham, pp 45-64. https://doi.org/10. 1007/978-94-007-5625-0_2

Horvitz L (1939) On geochemical prospecting. Geophysics 4:210-225

Hunt JM (1996) Petroleum geochemistry and geology, vol 2. WH Freeman, New York.

Jaafari, A., (1963). History and development of the Alborz and Sarajeh fields of Central Iran. In: 6th World Petroleum Congress. World Petroleum Congress.

Japperi NS, Hussein SNCM, Ab Lah NKIN, Dollah A, Othman NH, Azman NB (2019) Surface geochemical analysis on outcrop sample of block PM322 Shoreline, Pantai Bagan Lalang. Sci Lett 13(1):55-64. https://scilett-fsg.uitm.edu.my/

Laubmeyer G (1933) A new geophysical prospecting method, especially for deposits of hydrocarbons. Petroleum 29(1)

Miqueletto PB, Andreote FD, Dias ACF, Ferreira JC, dos Santos Neto EV, de Oliveira VM (2011) Cultivation-independent methods applied to the microbial prospection of oil and gas in soil from a sedimentary basin in Brazil. AMB Express 1(1):1-16. https://doi. org/10.1186/2191-0855-1-35

Mohammadi E (2020) Sedimentary facies and depositional environments of the Oligocene-early Miocene marine Qom Formation, Central Iran Back-Arc Basin, Iran (northeastern margin of the Tethyan Seaway). Carbonates Evaporites 35(1):1-29. https://doi. org/10.1007/s13146-020-00553-0

Mohammadi E, Hasanzadeh-Dastgerdi M, Safari A, VaziriMoghaddam H (2019) Microfacies and depositional environments of the Qom Formation in Barzok area, SW Kashan. Iran
Carbonates Evaporites 34(4):1293-1306. https://doi.org/10.1007/ s13146-017-0415-9

Morley CK, Kongwung B, Julapour AA, Abdolghafourian M, Hajian M, Waples D, Warren J, Otterdoom H, Srisuriyon K, Kazemi H (2009) Structural development of a major late Cenozoic basin and transpressional belt in central Iran: The Central Basin in the Qom-Saveh area. Geosphere 5(4):325-362. https://doi.org/10. 1130/GES00223.1

Morley CK, Waples DW, Boonyasaknanon P, Julapour A, Loviruchsutee $\mathrm{P}$ (2013) The origin of separate oil and gas accumulations in adjacent anticlines in Central Iran. Mar Petrol Geol 44:96-111. https://doi.org/10.1016/j.marpetgeo.2013.03.008

Philp RP, Crisp PT (1982) Surface geochemical methods used for oil and gas prospecting-a review. J Geochem Exploration 17(1): $1-34$

Rabbani AR (2017) Surface geochemistry and its application in the exploration of hydrocarbon resources. Amir Kabir University of Technology: Amir Kabir University of Technology (Tehran Polytechnic), p 158 (in Persian).

Rahimpour-Bonab H, Shariatinia Z, Siemann M (2007) Role of rifting in evaporite deposition in the Great Kavir Basin, central Iran. Geol Soc Lond Spec Publ 285(1):69-85. https://doi.org/10.1144/ SP2 85.5

Rasheed MA, Lakshmi M, Srinu D, Dayal AM (2011) Bacteria as indicators for finding oil and gas reservoirs: a case study of the Bikaner-Nagaur Basin, Rajasthan. India Petrol Sci 8(3):264268. https://doi.org/10.1007/s12182-011-0143-z

Rasheed MA, Lakshmi M, Rao PLS, Patil DJ, Dayal AM, Sudarshan V (2012a) Relevance of pentane-and hexane-utilizing bacterial indicators for finding hydrocarbon microseepage: a study from Jamnagar Sub-basin, Saurashtra, Gujarat. India Natural Resour Res 21(4):427-441. https://doi.org/10.1007/s11053-012-9189-x

Rasheed MA, Kalpana MS, Prasanna MV, Lakshmi M, Madhavi T, Tiwari DM, Patil DJ, Dayal AM, Raju SV (2012b) Geomicrobial and light gaseous hydrocarbon anomalies in the near surface soils of Deccan Syneclise Basin, India: implications to hydrocarbon resource potential. J Petrol Sci Eng 84:33-41. https://doi.org/10.1016/j.petrol.2012.01.010

Rasheed MA, Prasanna MV, Lakshmi M, Madhavi T, Kalpana MS, Patil DJ, Dayal AM (2012c) Geo-microbial prospecting studies of surface sediments from petroliferous region of the Mehsana Block, North Cambay Basin. J Geol Soc India 80(2):267-275. https://doi.org/10.1007/s12594-012-0137-5

Rasheed MA, Hasan SZ, Rao PLS, Boruah A, Sudarshan V, Kumar B, Harinarayana T (2015) Application of geo-microbial prospecting method for finding oil and gas reservoirs. Front Earth Sci 9(1):40-50. https://doi.org/10.1007/s11707-014-0448-5

Rasheed MA, Prasanna MV, Kumar TS, Patil DJ, Dayal AM (2008) Geo-microbial prospecting method for hydrocarbon exploration in Vengannapalli village, Cuddapah Basin, India. Curr Sci, pp 361-366 https://www.jstor.org/stable/24102760

Rasheed MA, Lakshmi M, Kalpana MS, Patil DJ, Dayal AM (2017) Recognition of hydrocarbon microseepage using microbial and adsorbed soil gas indicators in the petroliferous region of Krishna-Godavari Basin, India. Curr Sci 112(3):560. https:// www.jstor.org/stable/24912439

Reports of the Ministry of Oil of Iran (2019) Petroleum Ministry Islamic Republic of Iran.

Reuter M, Piller WE, Harzhauser M, Mandic O, Berning B, Rögl F, Kroh A, Aubry M-P, Wielandt-Schuster U, Hamedani A (2009) The Oligo-/Miocene Qom Formation (Iran): evidence for an early Burdigalian restriction of the Tethyan Seaway and closure of its Iranian gateways. Int J Earth Sci 98(3):627-650. https:// doi.org/10.1007/s00531-007-0269-9 
Rezaei MR, Honarmand J (2002) Parameters of Qom reservoir quality control in Alborz Field, Qom Basin, Central Iran. J Sci 27 (1):1 (in Persian).

Rosaire EE (1940) Geochemical prospecting for petroleum. Am Assoc Pet Geol Bull 24:1401-1433

Saberi MH, Rabbani AR, Ghavidel-syooki M (2016) Hydrocarbon potential and palynological study of the Latest Ordovician-Earliest Silurian source rock (Sarchahan Formation) in the Zagros Mountains, southern Iran. Mar Pet Geol 71:12-25. https://doi. org/10.1016/j.marpetgeo.2015.12.010

Schumacher D (2017. Minimize exploration risk: the impact of hydrocarbon microseepage surveys for distinguishing hydrocarbon-charged traps from traps without hydrocarbons. In: AAPG Annual Convention and Exhibition. https://www.researchgate. net/publication $/ 318753900$

Sechman H, Dzieniewicz M (2011) The example of background determination and mathematical processing of data from surface geochemical survey for the purposes of petroleum exploration. J Petrol Sci Eng 78(2):396-406. https://doi.org/10.1016/j.petrol. 2011.06.001

Sechman H, Mościcki WJ, Dzieniewicz M (2013) Pollution of nearsurface zone in the vicinity of gas wells. Geoderma 197:193204. https://doi.org/10.1016/j.geoderma.2013.01.012

Sechman H, Izydor G, Guzy P, Dzieniewicz M (2015) Surface geochemical exploration for hydrocarbons in the area of prospective structures of the Lublin Trough (Eastern Poland). Mar Pet Geol 61:22-38. https://doi.org/10.1016/j.marpetgeo.2014.12.001

Sechman H, Guzy P, Kaszuba P, Wojas A, Machowski G, Twaróg A, Maslanka A (2020) Direct and indirect surface geochemical methods in petroleum exploration: a case study from eastern part of the Polish Outer Carpathians. Int J Earth Sci 109:1853-1867 https:// doi.org/10.1007/s00531-020-01876-y

Sokolov VA (1933) The gas survey as a method of prospecting for oil and gas formations. Technika, NGRI 1

Tedesco SA (2012) Surface geochemistry in petroleum exploration. Springer, Cham
Thode H (1991) Sulphur isotopes in nature and the environment: an overview. Stable Isotopes Natural Anthropogenic Sulphur Environ 43:1-26

Thompson CD, Saunders DF, Burson KR (1994) Model advanced for hydrocarbon microseepage, related alterations. Oil Gas J (United States) 92(46). https://www.osti.gov/biblio/6845541-model-advan ced-hydrocarbon-microseepage-related-alterat

Varjani SJ (2017) Microbial degradation of petroleum hydrocarbons. Biores Technol 223:277-286. https://doi.org/10.1016/j.biortech. 2016.10.037

Wagner M, Wagner M, Piske J, Smit R (2002) Case histories of microbial prospection for oil and gas, onshore and offshore in northwest Europe. v 48:453-479. https://doi.org/10.1306/St48794C19

Whittenbury R, Phillips KC, Wilkinson JF (1970) Enrichment, isolation and some properties of methane-utilizing bacteria. Microbiology 61(2):205-218. https://doi.org/10.1099/00221287-61-2-205

Yang H, Meer FVD, Zhang J, Kroonenberg SB (2000) Direct detection of onshore hydrocarbon microseepages by remote sensing techniques. Remote Sens Rev 18(1):1-18. https://doi.org/10.1080/ 02757250009532381

Yuan Z, Zhang Y, Zhao Q, Jiang H, Liu Y, Luo Z, Li X, Wang S, Li B, Pan G (2009) New progress of microbial prospecting of oil and gas in China: Taking the Satellite Oilfield in Daqing as an example. Sci China Ser D Earth Sci 52(1):152-158. https://doi. org/10.1007/s11430-009-5016-6

Zhou Q, Xu X, Xu H, Zheng G, Pi W, Jiang Y, Xu X, Li Y, Wang J (2020) Surface microbial geochemistry of the Beihanzhuang Oilfield, northern Jiangsu, China. J Petrol Sci Eng 191:107140. https://doi.org/10.1016/j.petrol.2020.107140

Publisher's Note Springer Nature remains neutral with regard to jurisdictional claims in published maps and institutional affiliations. 